Sains Malaysiana 49(12)(2020): 3097-3104

http://dx.doi.org/10.17576/jsm-2020-4912-22

\title{
Surface Modification of Polyamide Ultrafiltration Membrane by Plasma Polymerisation of Acrylic Acid
}

(Pengubahsuaian Permukaan Membran Ultraturasan Poliamida dengan Pempolimeran Plasma Asid Akrilik)

\author{
A. Suhaimi, E. Mahmoudi, K.S. Siow \& M.F. Mohd RaziP WeE*
}

\section{ABSTRACT}

Increase in hydrophilicity of the filtration membrane could attribute to the fouling reduction and overall filtration performance. In this study, we employ a surface modification on polyamide (PA) membrane by using plasma polymerization with acrylic acid as the precursor by varying the deposition time from 1 to 10 min to induce hydrophilic surface of the membrane without changing the bulk properties of PA membrane. Cross-flow filtration of humic acid using the modified PA membrane was conducted to measure permeates flux and rejection. We calculate the fouling tendencies of each membrane and the result indicates the best performance from sample with 7 min deposition time in terms of permeate flux, rejection and the lowest fouling tendencies. Therefore, this proposed technique could be useful to further improve the commercial filtration membrane; without changing the membrane fabrication process.

Keywords: Acrylic acid; cross-flow filtration; filtration membrane; hydrophilicity; surface modification

\section{ABSTRAK}

Peningkatan hidrofilik membran penurasan boleh dikaitkan dengan pengurangan kotoran dan prestasi penurasan secara keseluruhan. Dalam kajian ini, kami menggunakan pengubahsuaian permukaan pada membran poliamida (PA) dengan menggunakan teknik pempolimeran plasma dengan asid akrilik untuk mendorong permukaan hidrofilik membran tanpa mengubah sifat pukal membran PA. Masa yang digunakan untuk proses pengubahsuaian permukaan dipelbagaikan dari 1 ke 10 minit. Penurasan asid humik menggunakan membran PA yang diubah suai dilakukan untuk mengukur kadar pengeluaran air tapisan dan kadar penurasan kotoran dalam air. Kami menghitung kecenderungan kotoran setiap membran dan hasilnya menunjukkan prestasi terbaik pada sampel dengan masa pemendapan 7 min dari segi kadar pengeluaran air turasan, kadar turasan kotoran dalam air dan kecenderungan kotoran terendah. Oleh itu, teknik yang dicadangkan ini dapat meningkatkan lagi prestasi membran penurasan komersial tanpa mengubah proses fabrikasi membran.

Kata kunci: Aliran silang penurasan; asid akrilik; hidrofilik; membran penapisan; pengubahsuaian permukaan

\section{INTRODUCTION}

The rapid growth of dye, textile, automotive, and agriculture industries have a huge impact on the environmental pollution. The never-ending release of pollutant to the surrounding environment have contaminated water supply that can cause harm for human consumption and aquatic ecosystem. For decades, membrane technology has been used in waste water treatment. Application such as in membrane bioreactor (Ladewig \& Al-Shaeli 2017), micro and nanofiltration, forward and reverse osmosis had proven very effective in treating waste water from wastewater treatment, water recycling, desalination, to gas separation.

Despite the efficiency shown by membrane technology in wastewater treatment, membrane technology is facing one biggest issue which is membrane fouling. Fouling is the reduction of efficiency of the membrane in term of permeates flux and rejection capabilities. Fouling can occur when foulant accumulated on the surface of the membrane and also inside the pores of the membrane from long period of filtration process (Chung et al. 2017; $\mathrm{Hu}$ et al. 2016). Membrane fouling reduce the efficiency and increase operational and maintenance cost (Kumar et al. 2016). The popular method of reducing fouling is by surface modification of membrane where foreign functional groups or compounds are attached on the surface of membrane without modifying its bulk properties. Furthermore, the addition of functional groups could modified drastically the membrane characteristics such as the wettability, charges, anti-fouling, and adsorption capacities (Mahmoudi et al. 2018). 
Among various surface modification techniques, we propose a low pressure plasma polymerisation technique allowing a thin layer of polymer to be deposited that contains specific functional group depending on the monomer. This technique has various advantages such as room temperature process, nanoscale thickness; small amount of monomer, and does not produce any secondary waste with the distribution of polymers deposited on the surface is homogeneous on a large amount of area. It has also been employed in the membrane filtration due to its advantages using various precursor (Duan et al. 2017; Jeong et al. 2016; Suhaimi et al. 2020) compared to conventional chemical modification. In this study, acrylic acid was used as the precursor for the plasma polymerization because the deposition will add carboxyl group with high stability onto the surface of the membrane. The polar nature of carboxyl group can further increase the hydrophilicity of the membrane (Ayyaru \& Ahn 2017).

In this study, we conducted the deposition of Acrylic acid by plasma polymerisation on the surface of Polyamide membrane. The aim of this experiment was to increase the hydrophilicity of the membrane as it is proven that hydrophilic surface could reduce the fouling of a membrane (Shen et al. 2017; Younas et al. 2017; Yuan et al. 2018).

\section{MATERIALS AND METHODS}

The deposition using plasma polymerization of acrylic acid on PA membrane was carried out in a 7-inch diameter cylindrical quartz tube chamber, with a stainless steel plate connected to RF generator with a frequency of 13.56 MHz. The pressure inside the chamber is measured by a vacuum gauge located at the top. The details of this plasma deposition setup has previously been illustrated elsewhere (Ooi et al. 2018; Siow et al. 2020).
Prior to depositing, we exposed the samples to air plasma treatment ( $30 \mathrm{~W}, 150 \mathrm{mTorr}$ ) for $2 \mathrm{~min}$ to eliminate the contaminant on the membrane and to activate its surface. After air plasma treatment, the pressure inside the chamber was again evacuated to reach 30 mTorr before allowing acrylic acid to flow inside the chamber at 300 mTorr pressure. Four samples were produced by varying the deposition time at 1, 3, 7, and 10 min named as Samples $2,3,4$, and 5, respectively. We also added one untreated sample as control referred as Sample 1. The plasma power for acrylic deposition was kept constant at 50W. After deposition, we allowed the membrane to rest for $2 \mathrm{~min}$ before immersing half of the membrane in water to test the stability of the deposition. Then, the hydrophilicity of the membrane was tested by measuring the contact angle. $2 \mu \mathrm{L}$ of water droplet placed on top of the membrane and the picture taken before transferring them into ImageJ software for accurate measurement of contact angle.

$1 \mathrm{~cm}^{2}$ from the sample were cut and the weight (dry) was recorded before immersing in water overnight. The weight (wet) of the immersed membrane later recorded again to measure the porosity of the membrane.

The performance of all membrane samples were tested by measuring the pure water flux and humic acid flux. Humic acid was used in this experiment as they are the common pollutant found in contaminated water for various industries especially agricultural to be used as main compound in the fertilizer. It helps to help plant roots receive water, nutrients, and can dramatically increase yields (Pettit 2004). It could represent up to $50 \%$ of the total organic carbon (TOC) - dissolved organics in the natural waters.

In this study, the humic acid concentration was kept constant at $100 \mathrm{ppm}$ with initial $\mathrm{pH}$ of 7.4. The setup for cross-flow filtration is shown in Figure 1. Before the

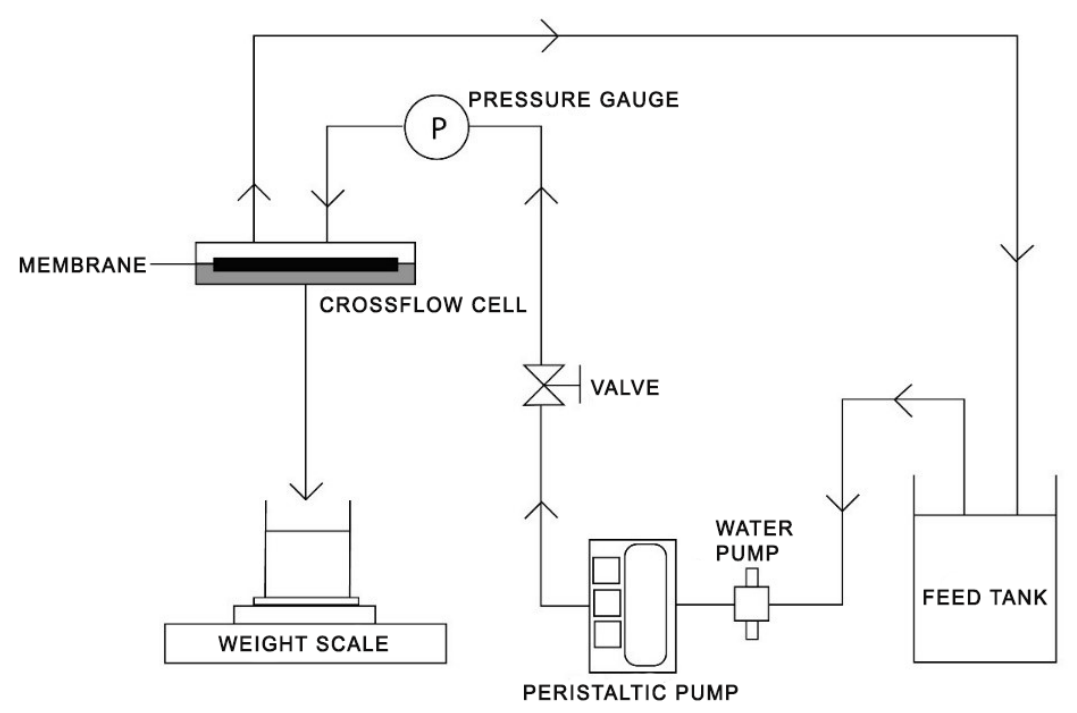

FIGURE 1. The Schematic diagram of the crossflow filtration system 
actual data can be recorded, the setup was let to run for one hour to accommodate the compaction time. The filtration process takes place for $90 \mathrm{~min}$ for pure water and $90 \mathrm{~min}$ for humic acid with constant water pressure at 3 Bars. The process then repeated for 3 times and the weight of permeate recorded for every $1 \mathrm{~min}$. Flux can be calculated with the following formula:

$$
J=\frac{\Delta v}{A \Delta t}
$$

where $\mathrm{J}$ is the permeate flux; is the permeate cumulative volume (L); $\mathrm{A}$ is the surface area of membrane $\left(\mathrm{m}^{2}\right)$; and is the filtration duration ( $\mathrm{min}$ ).

The fouling of membrane can be directly calculated based on the permeate flux recorded. Total fouling $\left(R_{t}\right)$, reversible fouling $\left(\mathrm{R}_{\mathrm{r}}\right)$, and irreversible fouling $\left(\mathrm{R}_{\mathrm{ir}}\right)$ can be calculated with the following formula

$$
\begin{gathered}
R_{t}=\left(1-\frac{J_{s o l}}{J_{w}}\right) \times 100 \% \\
R_{r}=\left(\frac{J_{w}-J_{w 2}}{J_{w}}\right) \times 100 \% \\
R_{\text {ir }}=R_{t}-R_{r}
\end{gathered}
$$

Rejection of humic acid is calculated by measuring the concentration of solution before filtration and concentration of the permeate. The concentration was measured by using photospectrometer with $250 \mathrm{~nm}$ wavelength. The concentration before and after filtration was added in the following formula to measure the rejection of humic acid by PA membrane.

$$
R=\left(1-\frac{C_{p}}{C_{f}}\right) \times 100 \%
$$

All the details for this formula can be found in our previous paper (Mahmoudi et al. 2019; Suhaimi et al. 2020).

\section{RESULTS AND DISCUSSION}

The aim of this paper was to produce a hydrophilic surface of the PA membrane. While untreated PA membrane is already hydrophilic, a more hydrophilic surface is expected. Contact angle testing shown in Figure 2 proves that the addition of acrylic acid plasma polymer on the surface of the membrane can increase the hydrophilicity of the membrane.

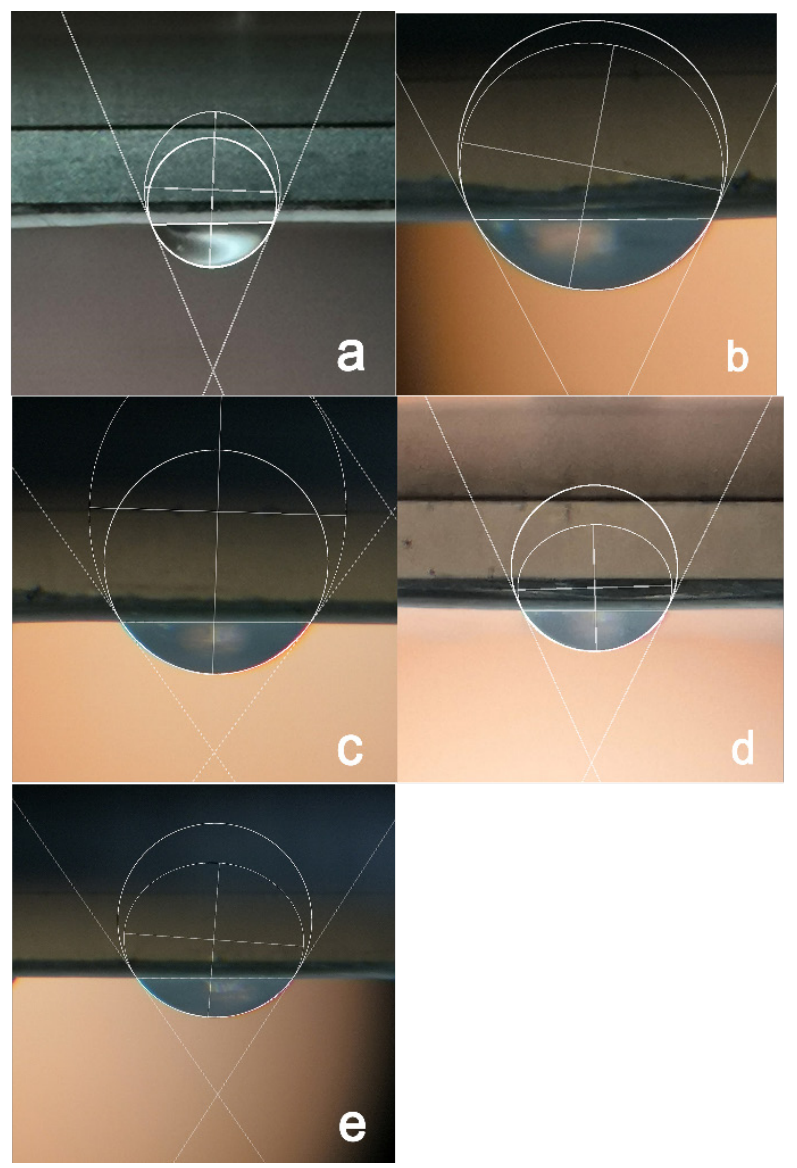

FIGURE 2. Contact angle of untreated membrane (a), sample 2

(b), sample 3 (c), sample 4 (d), and sample 5 (e) 
The contact angle for untreated PA membrane starts at $76^{\circ}$ and reduces after the treatment at $60^{\circ}$ (sample 2), $59^{\circ}$ (sample 3 ), $55^{\circ}$ (sample 4), and $53^{\circ}$ (sample 5). The reduction of contact angle shown in Figure 2 indicated that the hydrophilicity of the membrane increases. The increase of hydrophilicity of PA membrane is mainly affected by the functional group present in acrylic acid plasma polymer containing mainly of $\mathrm{COOH}$ carboxyl group which is a polar molecule (Gancarz et al. 1999). Addition of polar carboxyl group on top of a membrane further increases the adhesive force between the water molecule and the surface (Wang et al. 2018). Thus, the membrane surface attracts more water molecules than intramolecular within each other to further lower the water contact angle. Furthermore, the membranes showed an increase in porosity after the treatment. Figure 3 shows the porosity of membranes. Sample 1 showed the porosity of $50 \%$, sample 2 with $52 \%$, sample 3 with $53 \%$, sample 4 with $58 \%$ and sample 5 with $59 \%$. This increased porosity favoured increased membrane permeability with higher water flux. The increase in hydrophilicity also gives impact on the performance of PA membrane. Figure 4 shows the average pure water flux and normalized flux for all membrane samples. It shows that Samples 2, 3, and 5 have a lower overall flux and only sample 4 shows a higher flux when compared to untreated membrane. It shows that plasma polymerisation of acrylic acid have the optimum performance at 7 min treatment. The lower flux recorded for Samples 2 and 3 may occur due to the instability of the deposition. As mentioned in the methods section, the test was conducted for deposition stability by immersing the membrane in water. However, the higher pressure of water exerted on the membrane during filtration may produce an effect on the membrane surface. Plasma polymer has a critical thickness that allows the polymer to have stable deposition and $1 \mathrm{~min}$ and 3 min treatment may not give the critical thickness of a plasma polymer. On the other hand, the lower flux produced by sample 5 with 10 min treatment could be due to the domination of etching process during the deposition which could depend on various factors described by Yasuda (2012) as competitive ablation polymerization (CAP). It is proven in other studies that plasma polymerisation have an etching effect on the treated surface (Jeong et al. 2016). In this case, the etching occurs because of our process conditions especially the high power of $50 \mathrm{~W}$ and the time duration. Sample 5 with 10 min plasma treatment is sufficient to etch the membrane surface, thus, affecting the permeate flux. Therefore, we can conclude that $7 \mathrm{~min}$ treatment is the optimum time for plasma polymerisation of PA membrane that gives higher flux result when compared to untreated membrane.

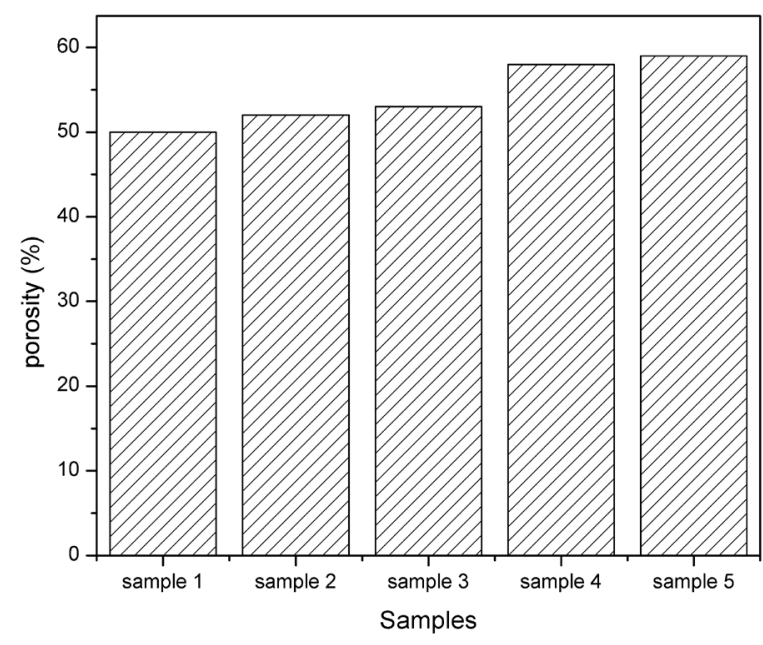

FIGURE 3. Porosity of all membrane sample

Even so, the calculation for antifouling properties of membrane shows a different result between treated membrane and untreated membrane. Based on Figure 5, sample 4 has the lowest total fouling at $20 \%$, followed by sample 3 at $25 \%$, and sample 2 at $30 \%$. This shows that incorporation of acrylic acid polymer on the surface of membrane reduces the fouling tendencies of membrane. Samples 2 and 3 also show reduce in fouling even with unstable deposition proposed as discussed earlier, showing that small amount of acrylic acid polymer is enough to 
reduce the fouling tendencies of membrane. However, sample 5 shows a fouling result that is comparable with the untreated membrane. The plasma etching may be the reason of this result as mentioned before; the etching damaged the surface of the membrane, thus, disrupts the
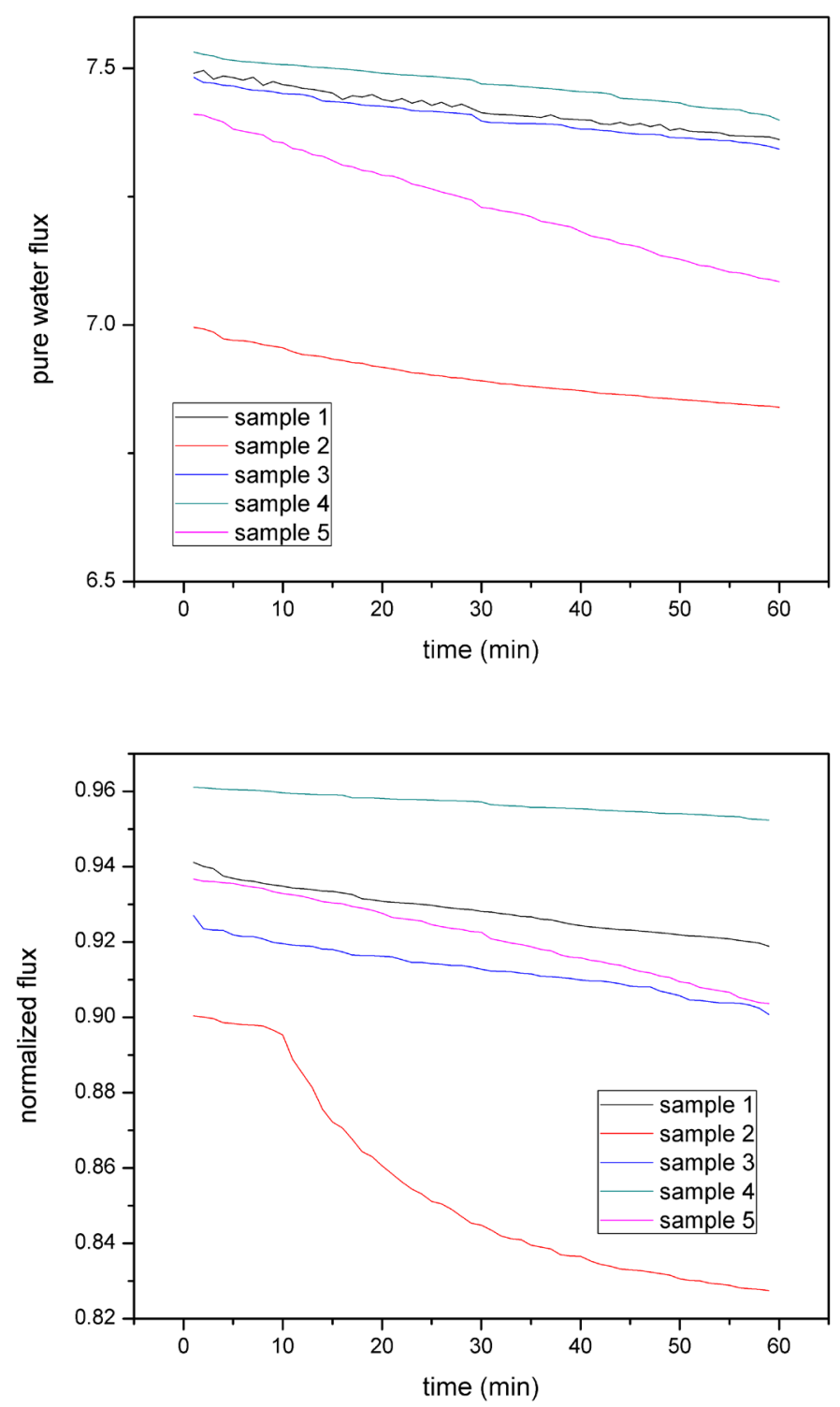

FIGURE 4. Average pure water flux and normalized flux for all samples

performance. The reduction in fouling of treated membrane is mainly due to the fact that the hydrophilicity of the membrane increases. Similar to the explanation earlier, the increase in hydrophilicity attracts more water molecule on the surface of the membrane and this will create a layer of water on top of the membrane surface that prevents the foulant to accumulate on the surface and also prevent the foulant to clog the pores of the membrane. This result is further backed up with the humic acid rejection result presented in Figure 6. Rejection of humic acid by PA membrane improves and increases with the treatment time when compared to untreated membrane with the exception of sample 5. Sample 1 gives $50 \%$ rejection, followed with sample 2 at 55\%, sample 3 at $58 \%$ and sample 4 at $71 \%$, while sample 5 gives $49 \%$ rejection of humic acid. Lastly, the $\mathrm{pH}$ value of permeate after filtration 
shows no change where the $\mathrm{pH}$ value before filtration was $\mathrm{pH} 7.4$ and $\mathrm{pH}$ after filtration decreased $\mathrm{pH}$ 7.1. The result presented proves that incorporation of acrylic acid on the surface of membrane increases the hydrophilicity of membrane and improves the performance of membrane.

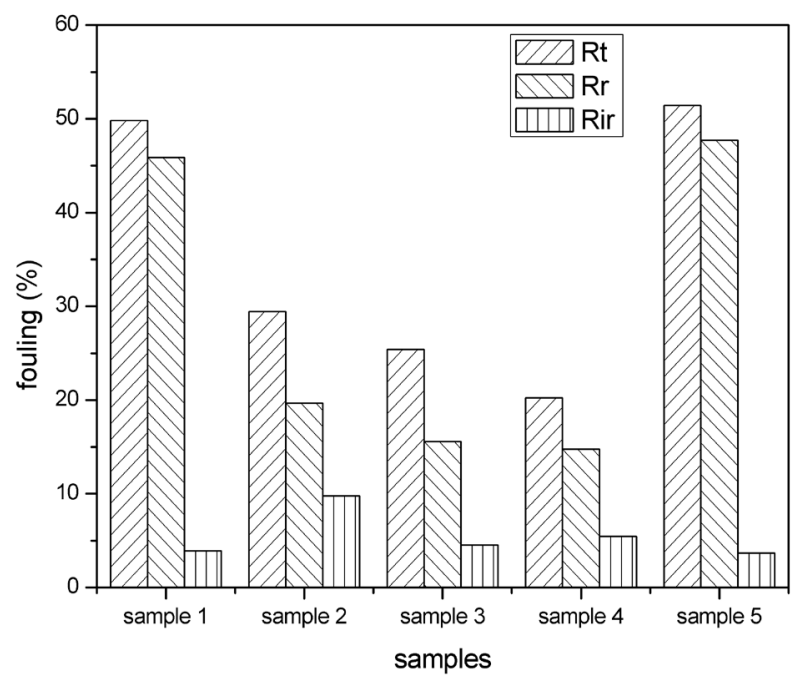

FIGURE 5. Total fouling, reversible fouling and irreversible fouling of all samples
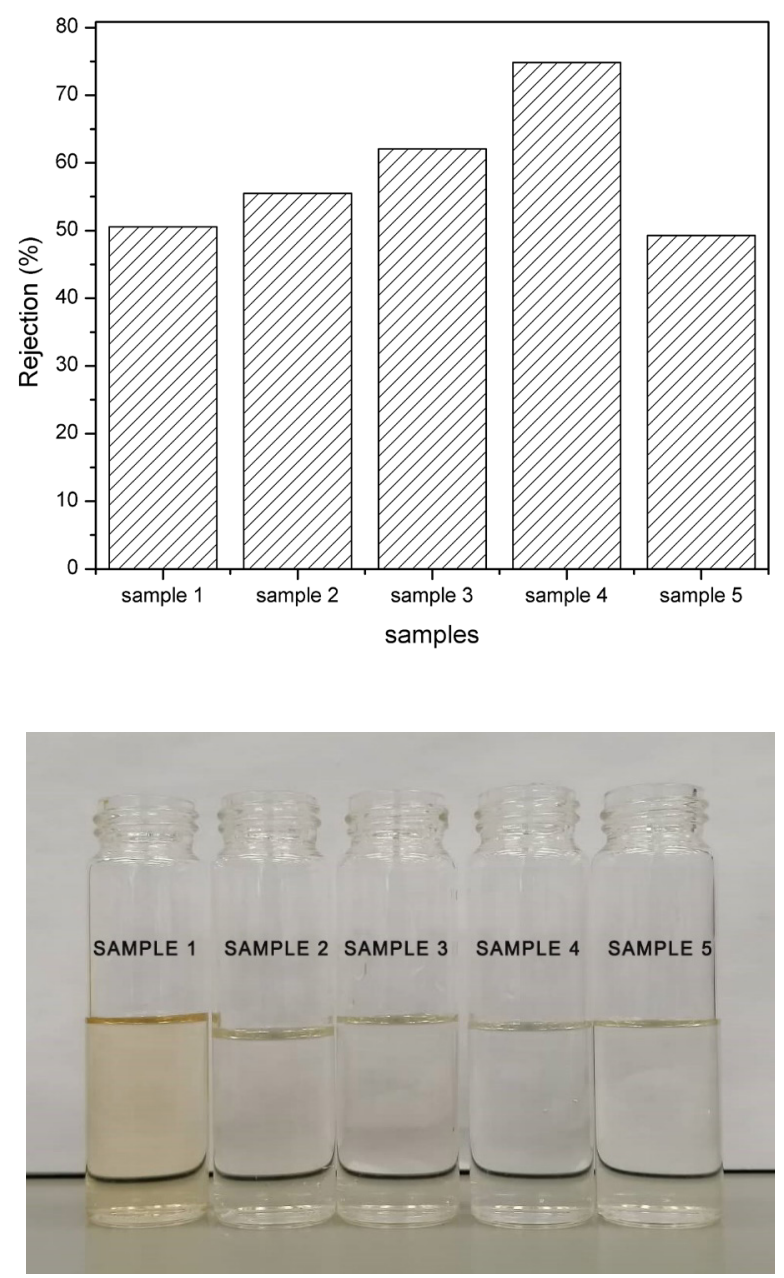

FIGURE 6. Rejection and the collection of permeates of humic acid after filtration of all samples 


\section{CONCLUSION}

We demonstrate the deposition of acrylic acid using plasma polymerisation technique to increase the hydrophilicity of Polyamide membrane in order to enhance the performance of the membrane. This experiment shows that small amount of acrylic acid polymer incorporated can increase the hydrophilicity of the membrane as shown with contact angle testing. However, the performance of membrane does not solely depend on the hydrophilicity alone. Correct parameter especially treatment time is essential for the optimum deposition to increase the overall performance of membrane. We concluded that 7 min treatment produces the best result in term of permeate flux, antifouling and rejection of membrane when compared to untreated membrane. We demonstrate the post process surface modification by plasma polymerization on the polyamide filtration membrane to improve its overall performance by changing the surface to be more hydrophilic in order to reduce its fouling.

\section{ACKNOWLEDGEMENTS}

Financial support for this research from the Ministry of Education, Malaysia and Universiti Kebangsaan Malaysia under the Grant GUP-2018-126 and AKU254:HICOE(FASA2) is gratefully acknowledged.

\section{REFERENCES}

Ayyaru, S. \& Ahn, Y.H. 2017. Application of sulfonic acid group functionalized graphene oxide to improve hydrophilicity, permeability, and antifouling of PVDF nanocomposite ultrafiltration membranes. Journal of Membrane Science 525: 210-219.

Chung, Y.T., Mahmoudi, E., Mohammad, A.W., Benamor, A., Johnson, D. \& Hilal, N. 2017. Development of polysulfone-nanohybrid membranes using $\mathrm{ZnO}-\mathrm{GO}$ composite for enhanced antifouling and antibacterial control. Desalination 402: 123-132.

Duan, S., Liu, X., Wang, Y., Meng, Y., Alsaedi, A., Hayat, T. \& Li, J. 2017. Plasma surface modification of materials and their entrapment of water contaminant: A review. Plasma Processes and Polymers 14(9): 1600218.

Gancarz, I., Poźniak, G., Bryjak, M. \& Frankiewicz, A. 1999. Modification of polysulfone membranes. 2. Plasma grafting and plasma polymerization of acrylic acid. Acta Polymerica 50(9): 317-326.

Hu, M., Zheng, S. \& Mi, B. 2016. Organic fouling of graphene oxide membranes and its implications for membrane fouling control in engineered osmosis. Environmental Science \& Technology 50(2): 685-693.

Jeong, S., Shin, B., Jo, W., Kim, H.Y., Moon, M.W. \& Lee, S. 2016. Nanostructured PVDF membrane for MD application by an $\mathrm{O}_{2}$ and $\mathrm{CF}_{4}$ plasma treatment. Desalination 399: 178-184.

Kumar, R.V., Goswami, L., Pakshirajan, K. \& Pugazhenthi, G. 2016. Dairy wastewater treatment using a novel low cost tubular ceramic membrane and membrane fouling mechanism using pore blocking models. Journal of Water Process Engineering 13: 168-175.

Ladewig, B. \& Al-Shaeli, M.N.Z. 2017. Fundamentals of Membrane Bioreactors: Materials System and Membrane Fouling. Gateway East: Singapore. Springer Singapore. pp. 13-38.

Mahmoudi, E., Ng, L.Y., Ang, W.L., Chung, Y.T., Rohani, R. \& Mohammad, A.W. 2019. Enhancing morphology and separation performance of polyamide 6,6 membranes by minimal incorporation of silver decorated graphene oxide nanoparticles. Scientific Reports 9(1): 1216.

Mahmoudi, E., Ng, L.Y., Mohammad, A.W., Ba-Abbad, M.M. \& Razzaz, Z. 2018. Enhancement of polysulfone membrane with integrated $\mathrm{ZnO}$ nanoparticles for the clarification of sweetwater. International Journal of Environmental Science and Technology 15(3): 561-570.

Ooi, P.C., Wee, M.M.R., Dee, C.F., Yap, C.C., Salleh, M.M. \& Majlis, B.Y. 2018. Fabrication of transparent bistable switching memory device using plasmapolymerized hexamethyldisiloxane layers with embedded graphene quantum dots. Thin Solid Films 645: 45-50.

Pettit, R.E. 2004. Organic matter, humus, humate, humic acid, fulvic acid and humin: Their importance in soil fertility and plant health. CTI Research. pp. 1-17.

Shen, L., Wang, X., Li, R., Yu, H., Hong, H., Lin, H., Chen, J. \& Liao, B.Q. 2017. Physicochemical correlations between membrane surface hydrophilicity and adhesive fouling in membrane bioreactors. Journal of Colloid and Interface Science 505: 900-909.

Siow, K.S., Rahman, A.S.A., Ng, P.Y. \& Majlis, B.Y. 2020. Sulfur and nitrogen containing plasma polymers reduces bacterial attachment and growth. Materials Science and Engineering: C 107: 110225.

Suhaimi, A., Mahmoudi, E., Siow, K., Mohammad, A. \& Wee, M.M.R. 2020. Nitrogen incorporation by plasma polymerization of heptylamine on PES membrane for removal of anionic dye (Congo red). International Journal of Environmental Science and Technology. 10.1007/s13762020-02879-7.

Wang, K., Hou, D., Wang, J., Wang, Z., Tian, B. \& Liang, P. 2018. Hydrophilic surface coating on hydrophobic PTFE membrane for robust anti-oil-fouling membrane distillation. Applied Surface Science 450: 57-65.

Yasuda, H.K. 2012. Plasma Polymerization. London: Academic Press, Inc.

Younas, H., Bai, H., Shao, J., Han, Q., Ling, Y. \& He, Y. 2017. Super-hydrophilic and fouling resistant PVDF ultrafiltration membranes based on a facile prefabricated surface. Journal of Membrane Science 541: 529-540.

Yuan, S., Li, J., Zhu, J., Volodine, A., Li, J., Zhang, G., Van Puyvelde, P. \& Van der Bruggen, B. 2018. Hydrophilic nanofiltration membranes with reduced humic acid fouling fabricated from copolymers designed by introducing carboxyl groups in the pendant benzene ring. Journal of Membrane Science 563: 655-663. 
A. Suhaimi, K.S. Siow \& M.F. Mohd Razip Wee* Institute of Micro Engineering and Nanoelectronics Universiti Kebangsaan Malaysia

43600 UKM Bangi, Selangor Darul Ehsan

Malaysia

E. Mahmoudi

Department of Chemical and Process Engineering

Faculty of Engineering and Built Environment

Universiti Kebangsaan Malaysia

43600 UKM Bangi, Selangor Darul Ehsan

Malaysia

\section{E. Mahmoudi}

Centre for Sustainable Process Technology (CESPRO)

Faculty of Engineering and Built Environment

Universiti Kebangsaan Malaysia

43600 UKM Bangi, Selangor Darul Ehsan

Malaysia

*Corresponding author; email: m.farhanulhakim@ukm.edu.my

Received: 21 August 2020

Accepted: 28 August 2020 